\title{
The Us Recognition of Jerusalem: Aspects and Implications
}

\author{
Shahzad Hussain \\ Email: shahzadehussain@gmail.com \\ Shahzad Hussain: Mphil International Relations, Ndu, Islamabad.
}

\begin{abstract}
The status of Jerusalem lies at the heart of Palestine-Israel conundrum. Its disputed status is pelagus forsit for the resolution of the intractable Palestine conflict. The Palestinians have always regarded Eastern Jerusalem as capital of their future state under Two-nation solution. On the other side, Israel declared in 1998 to further expand Jerusalem by annexing the surrounding areas as well. This paper investigates the Trump administration's stance on relocating the US embassy from Tel Aviv to Jerusalem, its implications for Palestinian state and broad reactions of the world community.
\end{abstract}

Key words: Jerusalem, Palestinian conflict, Knesset, United Nations

\section{Introduction}

The status of Jerusalem lies at the heart of Palestine-Israel conundrum. Its disputed status is pelagus forsit for the resolution of the intractable Palestine conflict. The United Nations (UN) declared this city corpus separatum i.e. city under a special regime under its Partition plan of 14 May, 1948 under resolution $181^{1}$. However, as a result of first Arab-Israel war (1948-49) between a coalition of Arab states and the nascent Israel state, Israel assumed the de facto control of Western Jerusalem while Jordon took control of Eastern Jerusalem. On December 14, 1949, Israel declared Eastern Jerusalem as its capital ${ }^{2}$. This step was a violation of the UN resolution 181. Moreover, during Six Day war of 1967, Israeli forces captured Eastern Jerusalem as well from Jordon. Israel later expanded its municipal law to Eastern Jerusalem as well and in this way de facto sovereignty was extended to the whole city. In July 1980, Israel's Knesset approved "Basic Law: Jerusalem, Capital of Israel” bill which declared Jerusalem as the undivided city and capital of Israel $^{3}$. This motion was in stark contrast with the UN resolutions over Jerusalem and was condemned by international community. The UN Security Council also urged member states not to recognize Israeli sovereignty over Jerusalem by prohibiting them to shift their embassies to Jerusalem. The annexation of territory through use of force is inadmissible in international law. Therefore, Israel's annexation of Jerusalem is an unlawful act. In this regard, the declaration of Trump Administration to relocate American embassy from Tel Aviv to Jerusalem on the pretext of Embassy Act 1995 constitutes implied recognition of the sovereignty of Israel over Jerusalem. It is not only against the UN Resolutions but also undermines the Palestinian right of self-

\footnotetext{
1 “The History of Jerusalem”, Al Jazeera, 9 Dec. 2003. https://www.aljazeera.com/archive/2003/12/20084916191675293.html (Accessed 25 April, 2018) ${ }^{2}$ ibid

${ }^{3}$ David B. Green, “This Day In Jewish History // 1980:Israel Enacts the Symbolic 'Jerusalem, Capital of Israel’ Law," Haaretz, 30 Jul. 2015. https://www.haaretz.com/jewish/.premium-1980-jerusalem-capital-of-israel-enacted-1.5380650 (Accessed 2 May, 2018)
} 
determination because Palestinians consider Eastern Jerusalem as the capital of their future state. This decision downplays the prospect of peace dialogue between Israel and Palestine and undermines the success of Two-nation solution. Succinctly, this research paper will explore the dynamics of Trump's decision vis-a-vis its illegality under international law and implications for Palestinian right of selfdetermination.

Neoclassical realism is a shade of realist school of thought which combines domestic and international variables to explain the foreign policy acts of a state. It contends that both external and internal variables mould the foreign policy acts of a state. Externally, these variables include power distribution among world states and anarchic world system where every state tends to secure its national interests. On domestic grounds, these variables include monopoly of the elite of a country, influence of certain pressure groups, role of major state institutions, cognitive bias of a leader, lobbies and public pressure. Neo-realism takes into account all these factors while justifying the foreign policy endeavors of a state.

Neoclassical realism can be applied to explain the decision of American administration under Donald Trump to recognize Jerusalem as the capital of Israel. Currently, the Muslim world is divided over several issues like Yamen and Syria. The Qatar issue has also created a rift among Arab states. These factors have deteriorated the unity of Arab states over Palestine issue. Moreover, a rapprochement is going on between Israel and Kingdom of Saudi Arabia (KSA) ever since Prince Muhammad bin Salman has taken the reins of Saudi Administration. These developments have weakened the traditional patronization of Palestine cause by the Arab world. Similarly, it was indeed one of the election promises of Trump to relocate American embassy from Tel Aviv to Jerusalem. He publically stated to work very closely with Israel which shows his cognitive bias towards Israel. Also there is a strong Jewish lobby in America like Adelsons group which molded the foreign policy of America vis-a-vis Palestine-Israel Issue.

John J.Meairsheimer and Stephen Walt, in their distinguished book "The Israel lobby and U.S Foreign Policy" accentuated the role of a loose coalition in the US of certain individuals and organizations who actively work for molding the US foreign policy in favor of Israel ${ }^{4}$. The sole purpose of these lobbyists is to seek maximum available American aid for Israe ${ }^{5}$. However, after a long time, finally the pro-Israel lobbies in the US have succeeded in convincing an American president to relocate the US embassy from Tel Aviv to Jerusalem bypassing the UN resolutions and principles of International law.

\section{Religious Sanctity Of Jerusalem}

Jerusalem is also known as al-Quds in Arabic. It is a holy place for all three Abrahamic religions i.e. Islam, Christianity and Judaism. For Muslims, Jerusalem is the third holiest place on earth. It is also home to al-Aqsa mosque. Muslims offered prayer in its direction for the first one and half year of Islam. The Dome of Rock which the Muslims hold very sacred is also situated in Jerusalem. It is the place where Prophet Muhammad (SAWW) ascended while he was travelling to heaven. Likewise, Jerusalem is also home to al-Haram al-Sharif. It is the site where Prophet Ibrahim went to sacrifice his son Ismail. This Noble Sanctury holds same importance for the followers of all divine religions. To be precisely,

\footnotetext{
${ }^{4}$ Johan J Meirsheimer and Stephen M. Walt, "The Israel Lobby and U.S Foreign Policy", Penguin, 2008, p.113 5 ibid
} 
Jerusalem is said to be the spiritual capital of the followers of all divine religions.

\section{Historical Background Of Jerusalem}

Jerusalem was the capital of Palestine when it was a mandate territory under the Britain Empire. When the tenure of mandate was about to end, both Arabs and Jews sought to take control of this sacred city. Meanwhile, Christians proposed that the city should b kept open to the followers of all divine religions. When this issue came to the $\mathrm{UN}$, the idea of internationalization of Jerusalem prevailed over all others options. Thus it was declared corpus separatum by the UN under its Master Plan about the division of Palestine.

However, Israel was able to gain de facto control of Jerusalem as a result of successive wars with Arab states. Israeli forces captured Western Jerusalem during First Arab-Israel War of 948. After the Six Day war in 1967, Israeli forces took control of Eastern Jerusalem as well which was earlier in the control of Jordon. Israel soon extended its municipal law to whole city ignoring its internationalization by the United Nations under resolution 181. To add fuel to fire, the undeterred Israel made Jerusalem its capital through a bill approved by Knesset in July 1980. Since this decision was a sheer breach of the UN resolutions and international law, it met serious condemnation by whole world. The UN also asked nations not to relocate their diplomatic missions to Jerusalem.

The Palestinians have always regarded Eastern Jerusalem as capital of their future state under Two-nation solution. On the other side, Israel declared in 1998 to further expand Jerusalem by annexing the surrounding areas as well ${ }^{6}$. Although Israel later announced to cancel this initiative due to worldwide pressure, it has been annexing the surrounding towns since the beginning of the second Intifada in 2000. However, these settlements have been declared unlawful by the International Court of Justice in 2004 as well. In a nutshell, the status of Jerusalem is a flashpoint of Palestine-Israel conflict.

\section{Us Recognition Of Jerusalem}

Despite the fact that Israel made Western Jerusalem its capital in 1949, no state stationed its diplomatic mission in this city in respect with the internationalized status of city. When again in 1980 Israeli Knesset approved a bill declaring Jerusalem an undivided city and Israel's capital, the whole world condemned it as it was against the resolutions of the UN. America also condemned this move by Israeli administration. Despite strong relations of America with Israel, the US didn't recognize sovereignty of Israel over Jerusalem. It played a role of peace broker and mediator between Palestine and Israel for decades However, American Congress approved a bill termed as Embassy Act 1995 after the victory of the Republican Party in the US midterm elections of 1994. This bill demanded American administration to recognize Jerusalem as an undivided city and capital of Israel. It was the first time when America changed its policy towards the status of Jerusalem. This bill was passed with heavy majority in the both houses of American Congress. It became law without the signature of president on $8^{\text {th }}$ November 1995.

\footnotetext{
${ }^{6}$ Philip Shenon, "Israel Said to Assure U.S. on Jerusalem Expansion”, The New York Times, 23 June 1998. https://www.nytimes.com/1998/06/23/world/israel-said-to-assure-us-on-jerusalem-expansion.html ( Accessed 2 May, 2018)
} 
The Jerusalem Embassy Act (1995) stated that ${ }^{7}$ :

1. Jerusalem should remain undivided city where the rights of the people of all religions are safeguarded.

2. Jerusalem should be recognized as the capital of Israel.

3. The US embassy in Israel should be relocated to Jerusalem from Tel Aviv by $31^{\text {st }}$ May 1999.

Basically, the Embassy Act also aimed at setting aside funds for relocating American embassy to Jerusalem from Tel Aviv. Meanwhile, the president was also permitted to invoke a waiver of six months to postpone this shifting of the US Embassy on the grounds of national security. President Clinton, Bush and Obama invoked this waiver time and again in their respective tenures to prevent the migration of embassy.

Conversely, Trump administration changed the policy of previous administration over the status of Jerusalem. President Donald Trump also signed a waiver in June 2017, but he announced to relocate embassy on 6 December 2017. Later on $23^{\text {rd }}$ February, Trump declared that the US diplomatic mission would be relocated to Arnona Consular Service site in Jerusalem from existing embassy in Tel Aviv. The figure 1 shows the new location of American embassy. It was earlier the American Consulate General in Jerusalem. The US embassy was officially moved to Jerusalem on 14 May 2018. Interestingly, the move coincided with the $70^{\text {th }}$ anniversary of Israeli Declaration of Independence ${ }^{8}$. The Palestinians are highly opposed to this move. They also remember $14^{\text {th }}$ May as "Naqba" i.e. the day of catastrophy.

\section{Response Of The World States Against The Us Decision}

The US decision to relocate embassy from Tel Aviv to Jerusalem is widely condemned across the globe. The Chief of foreign Policy of European Union, Federica Moghirini condemned American decision in very strong words and remarked that the Trump's decision would take us to darker times ${ }^{9}$. Moreover, the ambassadors of the major European States including France, the UK, Germany, Sweden etc released a common statement in SC condemning the US move over Jerusalem ${ }^{10}$. Similarly, all the Muslim states also sharply criticized this move. In many parts of the world, rallies were conducted to show solidarity with the Palestinians. OIC convened a conference to lodge its protest against the decision of Trump Administration.

\footnotetext{
${ }^{7}$ Thomas L. Friedman, “Foreign Affairs; O Jerusalem,” New York Times, 14 May,1995. https://www.nytimes.com/1995/05/14/opinion/foreign-affairs-o-jerusalem.html (Accessed on 6 May, 2018 )

8 "US to open jerusalem embassy in May for Israel's $70^{\text {th }}$ anniversary, 24 Feb. 2018, DAWN, https://www.dawn.com/news/1391416 (Accessed 8 May, 2018)

9 “Judith Michki”, “Mogherini: Trump's Jerusalem decision very worrying”, Politico, 7 Jul. 2017, https://www.politico.eu/article/federica-mogherini-donald-trump-jerusalem-decision-very-worrying/ ( Accessed 10 May, 2018)

${ }^{10}$ Rick Gladston “U.S. Faces Blunt Criticism at U.N. Over Jerusalem Decree”, The New York Times, 8 Dec. 2017, https://www.nytimes.com/2017/12/08/world/middleeast/un-jerusalem-security-council.html (Accessed 9 May, 2018)
} 


\section{US Jerusalem Embassy}

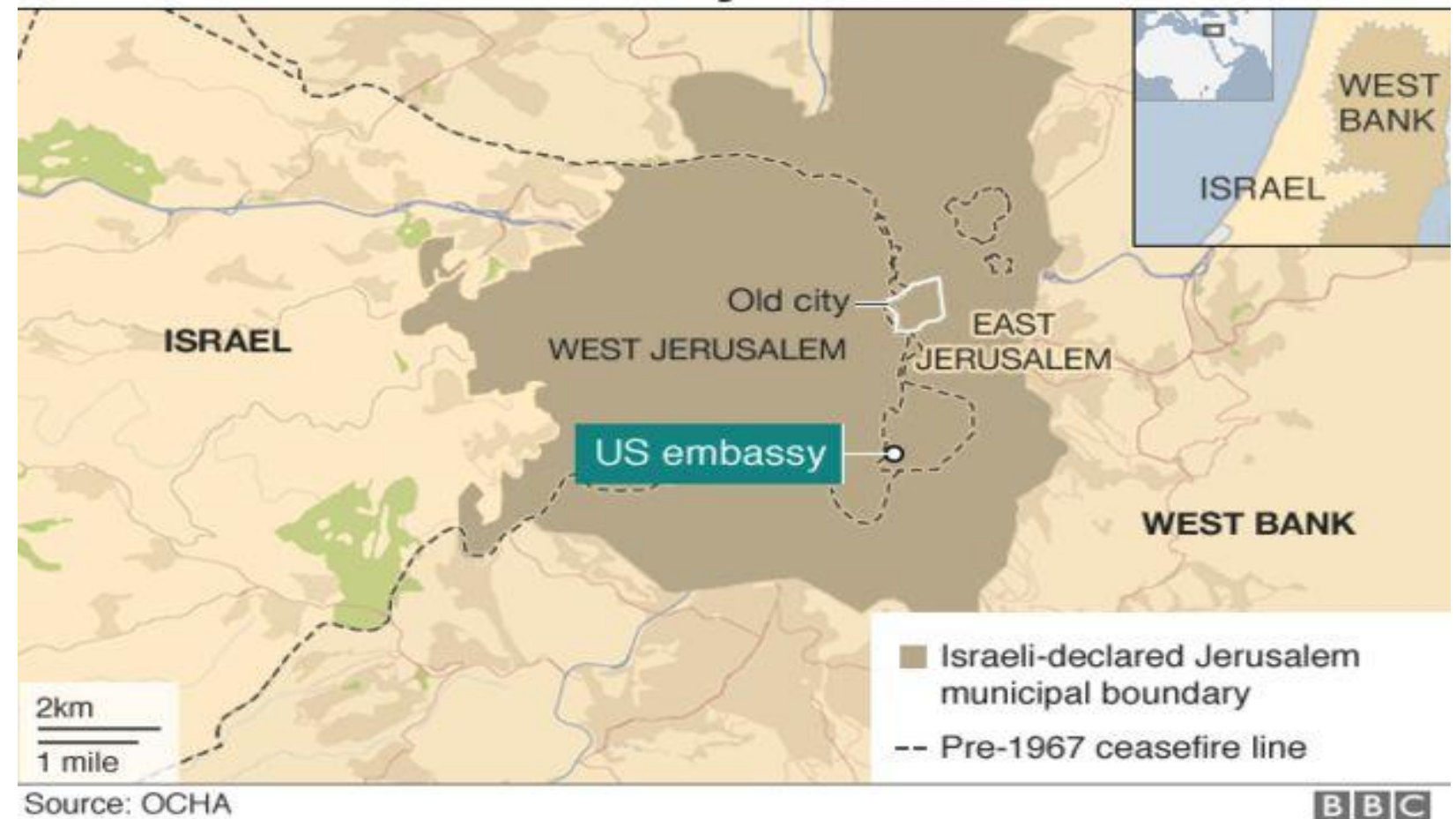

(Figure- $1^{11}$ )

\section{Factors Behind Shift In American Policy}

Donald Trump's decision to recognize the sovereignty of Israel over Jerusalem lies in his personal orientation, electoral pledges, extreme right and evangelical vote bank and active lobby of Jewish groups in America. Trump, while campaigning for presidency, categorically vowed that he would work with Israel very closely. He said he would be a very true friend of Israel and work very closely with it. ${ }^{12}$ Interestingly, just ten days before the presidential inauguration of Donald Trump, a Republican donor and renowned Jewish philanthropist Sheldon Gery Adelson had a private meeting with Trump in New York. After this meeting, Sheldon Gery apprised Morton A. Klein who was the head of Zionist Organization of America (ZOA) that Mr. Trump was determined to relocate American embassy from

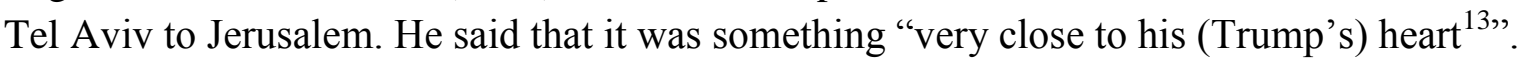

Furthermore, Marker Lander established the links between Trump's candidacy campaign and massive donation by Sheldon Adelson ${ }^{14}$. He argued that pro Trump campaign received a donation of worth $\$ 20$ million by Mr. Adelson. He further argued that Mr. Adelson also dedicated around $\$ 1.5$ million to

\footnotetext{
11 “Gaza clashes: 52 Palestinians killed on deadliest day since 2014,” BBC News, 14 May 2018. https://www.bbc.com/news/world-middle-east-44104599 (Accessed 17 May, 2018)

${ }^{12}$ Jenna Johnsen, "I will give you everything.' Here are 282 of Donald Trump's campaign promises." The Washington Post, 28 Nov. 2016. https://www.washingtonpost.com/politics/i-will-give-you-everything-here-are-282-of-donald-trumpscampaign-promises/2016/11/24/01160678-b0f9-11e6-8616-52b15787add0_story.html?utm_term=.d58b48924d43 ( Accessed 10 May, 2018 )

${ }^{13}$ Jonathen Freeland, "Donald Trump's Jerusalem statement is an act of diplomatic arson", The Guardian, 6 Dec. 2017. https://www.theguardian.com/commentisfree/2017/dec/06/donald-trump-jerusalem-statement-capital-israel-middle-east (Accessed 9 May, 2018)

${ }^{14}$ Mark Landlar, "For Trump, an Embassy in Jerusalem Is a Political Decision, Not a Diplomatic One", New York Times, 6 Dec. 2017. https://www.nytimes.com/2017/12/06/us/politics/trump-embassy-jerusalem-israel.html (Accessed 10 May, 2018)
} 
organize a Republican convention of pro Trump candidacy committee. Likewise, Peter Stone, while writing for Guardian, stated that Sheldon Gery Adelson had contributed \$25 million for Trump's presidential campaign. This shows the massive funding of Trump's electoral and presidential campaign by pro Israeli American Jews.

Similarly, the evangelical Christians in the US also motivated Trump to take decision about the pending status of the US embassy in Israel. The evangelical and Bible-believing Christians voted for Trump during presidential elections. They are believed to have a special bond of attachment with Israel. Due to their pro-Israeli character, they wanted Trump to recognize Jerusalem as the capital of Israel. Mark Landler quoted Tony Perkins who was the President of the Family Research Council and attended various meetings which took place between the representatives of evangelical Christians and Trump. Tony recalled that during these meetings, the special affiliation and bond of attachment between the Evangelical Christians and Israel was communicated to Trump. This was intended to make him cognizant of the demands of evangelicals with respect to Israel ${ }^{15}$.

However, it is note-worthy that Trump Administration made pro-Israeli lobbies like Adelsons happier at the cost of angering Arab allied states. This implies that Trump's decision over Jerusalem was basically more a political imperative. It was not quite a cunning diplomatic move. The orthodox Christians and Jews lobbies were overwhelmed at the Jerusalem announcement of trump. It is evident from the fact that after the Trump's announcement, the Republican Jewish community got an ad printed in New York Times to pay their heartiest gratitude to Donald Trump. The slogan in the said ad portrayed President Donald Trump praying at the Western Wall. The ad stated that "President Trump, You promised. You delivered. Thank You for courageously recognizing Jerusalem as Israel's eternal capital" ${ }^{\prime 6}$. According to Freeland, President Trump fulfilled the most controversial promise of his election campaign out of 282 promises that he made in total.

\section{Status Of The Us Recognition Of Jerusalem Under International Law}

The decision of the US administration to recognize Israel's sovereignty over Jerusalem by relocating its embassy from Tel Aviv to Jerusalem is contrary to the principles of international law. It violates several key UN resolutions over Jerusalem especially resolution 181 which declared this city corpus separatum. Israel captured this city through use of force which is prohibited in international law. Therefore, it was condemned by world states through various General Assembly and Security Council Resolutions. This move is also in contrast with the view of international society which has favored the internationalization of Jerusalem at the end of British mandate. The UN General Assembly also strictly condemned the decision of Trump administration. However, the violation on the part of the US administration of international law can be established on various grounds. The illegality could be established on following grounds:

\section{Duty of Non-recognition:}

Israel took control of Eastern Jerusalem by use of force during successive Arab Israel wars. The annexation of a territory through war and other use of force methods are inadmissible in international

\footnotetext{
15 ibid

${ }^{16}$ Jonathen Freeland, "Donald Trump's Jerusalem statement is an act of diplomatic arson"
} 
law. It is a peremptory norm. Therefore, the annexation of Jerusalem by Israel is a breach of jus cogens. Hence, it is the duty of all states under international law not to recognize the Israeli sovereignty over Jerusalem. According to Article 41(2) of the Articles of the Responsibility of States for Internationally Wrongful Acts, it is not allowed to any state under international law to give recognition to an unlawful act of a state ${ }^{17}$. It implies that no country can recognize a situation which is in contrary to an established principle of law. Therefore, states are under legal obligation, sometimes, not to grant recognition.

Similarly, International Court of Justice in its Advisory Opinion (2004) asserted that Eastern Jerusalem and Gaza strip are occupied territories as per international law ${ }^{18}$. It declared Israeli settlements and separation walls illegal and reminded Israel that it was bound to follow the fourth Geneva Convention. Likewise, according to the legal commentaries of International Law Commission, it is the principle of customary international law not to recognize a territory captured through use of force. Furthermore, Friendly Relations Declaration of 1970 also affirmed that a terrirory which will be obtained by use of force cannot be recognized as lawful. James Crawford argues that if the illegality of an act is substantial and based on a peremptory norm (jus cogen) of international law, states are under an obligation not to extend recognition to that act. ${ }^{19}$

\section{Illegality of Israel's Claim over Jerusalem:}

The acquisition of territory by force is inadmissible in international law. The UN Security Council Resolution 478 that urged all states to withdraw their embassies from Jerusalem in the wake of enactment of a law by Knesset declaring Jerusalem Israeli capital, regarding Israel's occupation of Jerusalem is based on the same assumption. John Dugard in his book "Recognition and the United Nations" argues that it a principle reason which justifies the duty of other states of non-recognition of Jerusalem $^{20}$.

Since prohibition of aggression is a jus cogen norm under international law, Israeli claim of selfdefense after the Arabs attack in 1967 and principles of jus ad bellum i.e. just reasons to go to war cannot be applied in taking control of Jerusalem using force. The annexation of Eastern Jerusalem by Israel resulted from use of force in 1967 which also falls under act of aggression on the part of Israel.

\section{The United Nations Resolutions on Jerusalem:}

The United Nations has passed various resolutions over Jerusalem since 1967 condemning Israel's annexation, settlements and separation plans ${ }^{21}$. Resolution 252 of Security Council condemned Israeli occupation of Jerusalem and its aggressive acts. The Security Council Resolution 478 condemned the Israel's attempt to annex Jerusalem in 1980. Similarly Resolution 298 of SC categorically declared all Israeli steps to change the status of Jerusalem in 1971. Likewise the UN

\footnotetext{
${ }^{17}$ Draft Articles on the Responsibility of States for Internationally Wrongful Acts, Rep. of the ILC on the Work of its Fiftythird Session, UN GAOR, 56th Session, Supp. No 10, p 43, UN Doc A/56/10 (2001)

${ }^{18}$ Loureen Sayej, "President Trump's Recognition of Jerusalem: A Legal Analysis" Oxford Human Rights Hub Blog, 11 Dec.2017. http://ohrh.law.ox.ac.uk/president-trumps-recognition-of-jerusalem-a-legal-analysis/ ( Accessed on 13 May, 2018 )

${ }^{19}$ James Crawford, "The Creation of States in International Law" Oxford University Press, 2007, p. 160

${ }^{20}$ Johan Dougard, "Recognition and the United Nations" Cambridge University Press, 1987, p. 113

21 “UN Resolutions on Occupied East Jerusalem”, Al Jazeera, 7 Dec. 2017. https://www.aljazeera.com/news/2017/12/resolutions-occupied-east-jerusalem-171206081326131.html (Accessed 14 May, 2018)
} 
General Assembly and UNESCO have also passed several resolutions condemning Israel's actions over and in Jerusalem.

\section{Illegality of the US's Relocation of Embassy:}

As argued above, states are bound not to recognize unlawful situations. The recognition is classified into two categories: Express and Implied. Draft articles on the Responsibility of States assert that article 42(2) prohibits both express and implied recognition of any unlawful act of a state. The implied recognition could arise from establishing embassy in the capital of a state. Trump's decision to relocate the US embassy to Jerusalem falls in the category of implied recognition. It acknowledges Israel's sovereignty over Jerusalem which is an occupied territory and resulted from the use of force, thus, making it an unlawful act. In this way, the US clearly violates its duty under international law of non-recognition.

It must be noted that earlier America and other world states associated the location of diplomatic embassies with the act of recognition due to the internationalization of Jerusalem. Therefore, America now cannot present Embassy Act 1995 as an excuse to separate embassy's location from the recognition of sovereignty of Israel over Jerusalem. Further, although the world opinion towards Jerusalem has changed from internationalization of this city to a negotiated settlement between Palestine and Israel, it does not change the contested status of the city. Hence, the US administration has undermined not only the premises of international law but also the spirit of international cooperation.

\section{Implications For The Palestinian Right Of Self-Determination}

The right of self-determination is an inalienable right. This right lies at the heart of international humanitarian law and provides substance to it. The UN has been keenly advocating right of selfdetermination since its inception. As a fruit of the UN advocacy, many colonized nations got independence from their colonial masters. The UN General Assembly is often termed as the "collective conscience" of the world. It has recognized the fundamental right of self-determination in various resolutions $^{22}$. For instance, resolution 3314 of the General Assembly prohibited any military occupation of any territory of a country. Simultaneously, it also acknowledged the right of self-determination, freedom and independence of colonized people or any other deprived group of people under a racist regime. Furthermore, this resolution notes the right of occupied people to struggle for freedom and seek support from other sympathetic countries. Concept of self-determination has a strong locus standi in international law as well.

The Palestinian Authority (PA) led by Mehmud Abbas is leaving no stone unturned to achieve the right of self-determination for Palestinian people. It was established in 1994 as a result of Oslo Accord. It is an interim government of Palestinians which governs Gaza bank. It is the representative of thus more than 4 million Palestinian people at various global forums to discuss Palestine issue. It is striving hard to achieve Palestinian statehood through advocating the right of self-determination, international diplomacy and judicial actions against the criminal and unlawful acts of Israel. The Palestinian people favor the Two-State Solution to end prolonged Palestine-Israel conflict. According to this formula, a Palestinian state will be established in the Western Bank and Gaza. It will coexist with the Israeli state.

\footnotetext{
22 ibid
} 
The Obama administration also endorsed this idea ${ }^{23}$.

Since the status of Jerusalem is central to Palestine-Israel issue, inter alia, demarcation of borders, return of refugees and separation of walls, the recognition granted by the United States by relocating its embassy to Jerusalem has undermined the Palestinian right of self-determination. The Palestinian Authority (PA) and people see Eastern Jerusalem as the capital of their future state under Two-nation solution.

The US has long been a mediator and broker of dialogue between Palestine and Israel in solving the intractable Palestine issue. During Madrid Peace conference, which was hosted by Spain in 1991 to revive Palestine-Israel peace process, the US sent a letter to the Palestinian authorities to assure them that the US would favor a multilateral negotiation over the final status of Jerusalem ${ }^{24}$. The successive US administrations favored this stance. However, the recent step taken by Trump administration is thoroughly inconsistent with the longstanding official policy of the US over Jerusalem. It prejudges the status of Jerusalem without multilateral negotiations. It is also a dynamite under the pillars of American support to the Palestinian right of self-determination.

Now that the US has relocated its embassy to Jerusalem on May 14, the prospects of Two-nation solution are very dim. It is because Palestinians won't accept a settlement before deciding the status of Palestine. Moreover, the US move basically extends implied recognition to the annexation of Eastern Jerusalem by Israel as discussed above. Although Trump claimed that relocating embassy didn't imply the recognition of the boundaries of Jerusalem, yet the Israeli claim over Jerusalem has strengthened as a result of this development. Israel considers Jerusalem an undivided city and its permanent capital. It is not ready to negotiate over its status. Therefore, the scope of Two-nation solution has been constrained by the US step endangering Palestinian statehood ${ }^{25}$. The US now can never assume the role of honest broker of dialogue and mediator in the solution of Palestinian issue ${ }^{26}$.

Further, the internationalization of Jerusalem puts a duty on all world states of non-recognition of Israel's authority over this disputed city. Since Israel took control of Jerusalem by force, it evokes the denial of self-determination, freedom and independence to the Palestinian people. Therefore, all the states including the US have a legal obligation under international law of non-recognition of this unlawful act. In this context, ICJ under its Advisory Wall Opinion (2004) declared Jerusalem as an occupied territory and noted that it was obligatory for all states not to recognize unlawful situation arising from the illegal acts of Israel in Occupied Palestinian territory.

Virtually all the world states excluding the United States and Israel are of the view that by relocating the US embassy to Jerusalem and accepting Jerusalem as the undivided city and capital of Israel, the US has downplayed the hope of any meaningful hope of peace dialogue between Israel and Palestine in the near future. The status of this historical and sacred city was a serious challenge for diplomats involved in peace dialogue. Since Jerusalem is pivotal to the issue, its status should have been decided through negotiations between Israel and Palestine. However, the decision of Trump has not

\footnotetext{
23 "Obama Endorses Two-State solution for Arab-Israel Conflict”, Voice of America, 2 Nov.2009. https://www.voanews.com/a/a-13-2009-02-06-voa37-68673907/408643.html ( Accessed 15 May, 2018)

${ }^{24}$ Louren Sayej, “President Trump's Recognition of Jerusalem: A Legal Analysis”, Oxford Human Rights Hub Blog, 11 Dec.2017.

25 "Embassy Move has damaged peace process", The Baltimore Sun, 14 May, 2018. http://www.baltimoresun.com/news/opinion/editorial/bs-ed-0515-jerusalem-20180514-story.html (Accessed 17 May, 2018) ${ }^{26}$ ibid
} 
only eclipsed any hope of peace process but also damaged severely its role as an honest broker in this issue.

All the resolutions which the United Nations has passed relevant to the issue of Palestine affirm that any unlawful change in the status of Jerusalem would negatively affect the two-state proposal of solving this seemingly unending issue and thus any meaningful prospect of peace in the region. The recent declaration of the President Trump has destroyed the two-state solution of Israel-Palestine issue. Further, it also implies the denial of Palestinian right of self-determination. The incumbent secretary general of the UN remarked that this step by president Trump would undermine peace prospects and the status of Jerusalem should be decided by bilateral negotiations between Palestine and Israel.

In the context of Trump's move over Jerusalem, recently the UN general assembly again passed a resolution which affirmed the Palestinian right of self-determination and illegitimacy of Trump's decision $^{27}$. It declared the American move null and void. This resolution was passed with an overwhelming majority. Despite American warnings to the world states and Jewish lobby, 176 states voted in favor of the resolution while 7 states including the US, Israel and Canada opposed it. Also, 7 states abstained from voting. Similarly, the Inter-Parliamentary Union also endorsed Palestinian right of self-determination, its right to a separate state in the wake of Trump's policy statement over the status of Jerusalem. Surprisingly, the IPU also accepted Jerusalem as the capital of Palestine. The IPU voted in the favor of Palestine during its $138^{\text {th }}$ session, convened in Geneva Switzerland on 24-28 of March $2018^{28}$. The UN and IPU's endorsement clearly states that the international community considers American decision to be an unlawful act due to its derogatory effects for the Palestinian right of selfdetermination and the Two-state solution of the issue.

\section{Conclusion}

The unresolved status of Jerusalem is the flashpoint of seemingly unending Palestine crisis. Due to the religious sanctity, Jerusalem is equally important to the followers of all divine religions. Israel got took control of Jerusalem as a result of successive Arab-Israel wars. However, despite its internationalization by the UN, Israel declared Jerusalem its capital city in 1980 violating international law and the UN resolutions. Resultantly, the Security Council asked all member states to withdraw their diplomatic missions from Jerusalem in respect with UN resolutions over Jerusalem and Palestinian right of self-determination. However, the recent Trump administration's decision to relocate embassy to Jerusalem from Tel Aviv undermines Palestinian right to self-determination and downplays the probability of meaningful peace prospects between Israel and Palestine. The decision was motivated and influenced by Pro-Israel lobbies in America. It was taken in the pretext of the US Embassy Act 1995. This decision also changed the long followed American neutrality over the status of Jerusalem. Although Trump stated that relocating the embassy didn't predetermine the boundary of Jerusalem, yet it gives implied recognition to an unlawful annexation of Jerusalem by Israel. It was a violation of UN

\footnotetext{
27،Mythili Sampathkumar, "UN Jerusalem vote: General Assembly rules against US, declaring recognition of Israel capital 'null and void' ”, Independent, 21 Dec.2017.

https://www.independent.co.uk/news/world/middle-east/un-jerusalem-trump-vote-result-decision-general-assembly-nullvoid-a8123106.html (Accessed 23 May, 2018)

28“Inter-Parliamentary Union in Geneva Votes in Support of Jerusalem as Palestine's Capitol”, Albawaba News, 26 Mar. 2018.

https://www.albawaba.com/news/inter-parliamentary-union-geneva-votes-support-jerusalem-palestines-capitol-1107972 (Accessed 23 May, 2018)
} 
resolutions, ICJ's advisory opinions and principles of international law. The US violated a collective duty placed on all states by Draft Declaration on the Rights and Duties of States and Security Council's resolution 478 of non recognition of an unlawful situation created by Israel in Jerusalem. On the other side, the status of Jerusalem is a flashpoint of Palestine-Israel conundrum. The Palestinians consider Eastern Jerusalem to be the capital of their future state. By relocating their embassy to Jerusalem, the US has sabotaged the spirit of negotiations between Palestine and Israel over the status of this city further complicating the issue. In a nutshell, President Trump pleased the pro-Israel lobby in America at the cost of Palestinian right to self-determination.

\section{References:}

1. Merisheimer J Johan, and Stephen M. Walt. The Israel Lobby and U.S Foreign Policy. Penguin, 2008.

2. Shenon, Philip. "Israel Said to Assure U.S. on Jerusalem Expansion." New York Times, June 23, 1998.

3. Gladston, Rick “U.S. Faces Blunt Criticsm at U.N Over Jerusalem Decree”. New York Times, Dec. 8, 2017.

4. Freeland, Jonathan. "Donald Trump's Jerusalem statement is an act of diplomatic arson". Guardian, Dec. 6, 2017.

5. Crawford, James. The Creation of States in International Law. Oxford University Press, 2007.

6. Johnson, Jenna. "I will give you everything'. Here are 282 of Donald Trump's campaign promises." Washington Post, Nov. 28, 2016.

7. Dougard, Johan. Recognition and the United Nations. Cambridge University Press. 1987.

8. Green, David. "This Day in Jewish History// 1980: Israel Enacts the Symbolic 'Jerusalem, Capital of Israel' Law”. Haaretz, Jul. 30, 2015.

9. Friedman L, Thomas. "Foreign Affairs; O Jerusalem". New York Times, May 14, 1995.

10. Michki, Judith. “Trump's Jerusalem decision very worrying”. Politico, 7 July 2017.

11. Landlar, Mark. "For Trump, an Embassy in Jerusalem Is a Political Decision, Not a Diplomatic One". New York Times, Dec. 6, 2017.

12. Sayej, Loureen. "President Trump's Recognition of Jerusalem: A Legal Analysis". Oxford Human Rights Hub Blog, Dec. 11, 2017.

13. Sampathkumar, Mythili. "UN Jerusalem vote: General Assembly rules against US, declaring recognition of Israel capital 'null and void' ". Independent, Dec. 21, 2017.

14. Albawaba News. "Inter-Parliamentary Union in Geneva Votes in Support of Jerusalem as Palestine's Capitol”. Mar. 26, 2018.

15. Baltimore Sun. "Embassy Move has damaged peace process". May 14, 2018.

16. Voice of America. "Obama Endorses Two-State solution for Arab-Israel Conflict." Nov. 2, 2009.

17. Al Jazeera. "UN Resolutions on Occupied East Jerusalem”. Dec. 72017. 